\title{
Habitat Ecology and Biological Characteristics of a Hypersaline Ciliate, Fabrea salina from Solar Salterns of Mumbai Coast, India
}

\author{
Bam Deo Pandey ${ }^{1 *}$ and S G Yeragi ${ }^{2}$ \\ ${ }^{1}$ Udai Pratap College, India
}

${ }^{2} \mathrm{KJ}$ Somaiya College of Science \& Commerce, India

Submission: April 06, 2020; Published: August 03, 2020

Corresponding author: Bam Deo Pandey, Udai Pratap College, Varanasi, India

\begin{abstract}
The ecology of a hypersaline ciliate, Fabrea salina was studied in two saltpans along the Mumbai coast, India. There was an apparent trend of its seasonal abundance being maximum (up to $58 \times 10^{3}$ cells L $^{-1}$ in May) during late post- monsoon to summer months and complete disappearance during monsoon period. Being the most dominant species in microzooplankton community, it had an average annual density of $18 \times 10^{3}$ cells $\mathrm{L}^{-1}$. It flourishes well under higher temperature $\left(30-39^{\circ} \mathrm{C}\right)$ and salinity (40-150 \%o) conditions. Among phytoplankton, Dunaliella was the dominant one with a highest density of $58 \times 10^{3}$ cells $\mathrm{mL}^{-1}$ in April, followed by Chlorella with up to $42 \times 10^{3} \mathrm{cells} \mathrm{mL}^{-1}$, in March. The ANOVA test for physical and chemical variables has revealed significant difference $(\mathrm{P}=0.05)$ in their values in different months. Except in water temperature and $\mathrm{NO}_{2}-\mathrm{N}$, no significant difference was observed at various stations as the case with phytoplankton and zooplankton. There was strong positive correlation of Fabrea with water temperature $(\mathrm{r}=0.866,0.801)$, salinity $(\mathrm{r}=0.966,0.957)$, total alkalinity $(\mathrm{r}=0.717,0.729)$ and $\mathrm{PO}_{4}-\mathrm{P}(\mathrm{r}=0.750$, $0.897)$ while negative correlation with water depth $(\mathrm{r}=-0.767,-0.757)$ and $\mathrm{pH}(\mathrm{r}=-0.086,-0.411)$. Fabrea varies widely in its total length (60-600 $\mu \mathrm{m})$ and cyst diameter (70-180 $\mu \mathrm{m})$. The average length of body cilia is $12 \mu \mathrm{m}$ and the width of each adoral zone of membranelle (AZM) is $10 \mu \mathrm{m}$.

Kewords: Fabrea salina; Hypersaline ciliate; Solar salterns; Ciliate ecology
\end{abstract}

\section{Introduction}

Ciliates are the most specialized and perhaps most widely distributed and diverse group of protozoa having representatives in virtually all kinds of freshwater to marine environments, often in extremely high densities [1]. They form an important component of estuarine as well as coastal marine ecosystems as they feed upon bacteria and in turn serve as food for metazoans [2,3]. However, the ecology and biology combined with factors controlling the distribution of protists in tropics have received very little attention [4]. Many hypersaline environments are inimical to macroscopic life but are the preferred habitats of a variety of microorganisms. The heterotrichous ciliate, F. salina , reported from several diverse environments such as salt marshes, hypersaline lakes and solar salterns [5-7], has received much attention in the recent years primarily due to its potentiality as live food source for maricultural purposes [8-11] and also as an experimental animal in basic research of applied value in eukaryotic microbiology [12-16]. Though fairly a good amount of literature is available on the hydrobiology of estuaries and backwaters in India, the information on the plankton ecology in inland saline lakes and solar salterns is very scanty. The present study deals with the ecology of $F$. salina in two saltpans near Mumbai, West Coast of peninsular India, for a period of one year, January 1998 to December 1998.

\section{Study Area}

The study areas, Mira Road and Bhayandar saltpans, the parts of Thane District, Maharashtra, India, are located at $19{ }^{\circ} 16^{\prime} \mathrm{N}$ Lat

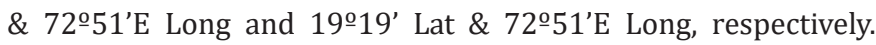
The former relates to Manori creek while the later with Bassein creek, along the Mumbai coastline. Two sampling stations in each saltpan, denoted as $\mathrm{MR}_{1} \& \mathrm{MR}_{2}$ at Mira Road and $\mathrm{BH}_{1} \& \mathrm{BH}_{2}$ at Bhayandar were selected in the present study. The region has typical tropical climate.

\section{Methods}

\section{Phytoplankton and Zooplankton}

For phytoplankton analysis, one-liter water was directly collected whereas zooplankton samples were taken by filtering 
$50 \mathrm{~L}$ of water through plankton net of $40 \mu \mathrm{m}$ mesh size. The samples were preserved with Lugol's solution. After three days of stagnation, the phytoplankton samples were concentrated to $100 \mathrm{~mL}$ volume by decanting the supernatant. Except Dunaliella that was counted by haemocytometer, all the plankton were enumerated using Sedgwick-Rafter cell counter $50 \mathrm{~mm} \times 20 \mathrm{~mm}$ $\mathrm{x} 1 \mathrm{~mm}$ ). For each month, the average density of Fabrea, Dunaliella and Chlorella were taken for statistical purposes.

\section{Hydrological and Soil-Quality Parameters}

Both ambient and water temperatures were measured using thermometer with $0.1^{\circ} \mathrm{C}$ accuracy while water depth by a meter scale. Salinity and $\mathrm{pH}$ were recorded at the site using Salinity Refractometer (S/Mill- E, Atago) and portable pH meter (Model No. E Merck 325). Other water quality parameters such as dissolved oxygen, dissolved free carbon dioxide, total alkalinity, ammonium- nitrogen $\left(\mathrm{NH}_{4}^{+}{ }^{+} \mathrm{N}\right)$, nitrite-nitrogen $\left(\mathrm{NO}_{2}-\mathrm{N}\right)$, nitratenitrogen $\left(\mathrm{NO}_{3}-\mathrm{N}\right)$ and phosphorus $\left(\mathrm{PO}_{4}-\mathrm{P}\right)$ were analyzed following Standard Methods (APHA, 1992) monthly. The values of various parameters obtained at both the stations of each saltpan were summed up and average values are used in data analysis. The soil-quality parameters viz. percentage of sand, silt, clay, organic carbon, organic matter and total nitrogen and phosphorus (mg/100 g of soil sample) were analyzed following Ghosh et al. [17] during pre- monsoon, monsoon, and post-monsoon periods.

\section{Encystment and Excystation}

To validate the existence of $F$. salina in encysted form during the periods of non- availability of its free-swimming trophozoites in nature, the sun-dried scum-mat with some soil of salt-pans was immersed at $5 \mathrm{~g} \mathrm{~L}^{-1}$ in saline water ( $2 \mathrm{~L}$ ) of six different salinities i.e. $30,40,50,60,80$ and $100 \%$ provided with mild aeration. For encystment, the salinity of culture medium ( $5 \mathrm{~L}$ ) was raised gradually from 65 to $110 \%$. After harvesting, the cysts were subjected to hatching under different salinities as indicated above. These experiments were carried out at ambient and water temperature of $34 \pm 1^{\circ} \mathrm{C}$ and $31 \pm 1^{\circ} \mathrm{C}$, respectively.

\section{Results}

\section{Phytoplankton and Zooplankton}

Phytoplankton and zooplankton were in abundance during pre- and post- monsoon months while their density was quite low in monsoon periods (Table 1-4). Zooplankters were completely absent during July and August months. Dunaliella, the most abundant species noted, was with a maximum density of $57 \mathrm{x}$ $10^{3}$ cells $\mathrm{mL}^{-1}$ during April. Chlorella, the second largely available plankton, had the highest density of $40 \times 10^{3} \mathrm{~mL}^{-1}$ in March. This was followed by the occurrence of Nitzschia sp., Navicula sp., Anabaena, Oscillatoria and Rhizosolenia.

Table 1: Phytoplankton composition at different stations of Mira Road saltpan ( No./ml; values are $\times 10^{3}$ ).

\begin{tabular}{|c|c|c|c|c|c|c|c|c|c|c|c|c|c|c|}
\hline \multirow[t]{2}{*}{ Month } & \multicolumn{2}{|c|}{$\begin{array}{c}\text { Dunaliella } \\
\text { sp. }\end{array}$} & \multicolumn{2}{|c|}{$\begin{array}{c}\text { Anabaena } \\
\text { sp. }\end{array}$} & \multicolumn{2}{|c|}{$\begin{array}{c}\text { Chlorella } \\
\text { sp. }\end{array}$} & \multicolumn{2}{|c|}{$\begin{array}{c}\text { Oscillatoria } \\
\text { sp. }\end{array}$} & \multicolumn{2}{|c|}{$\begin{array}{c}\text { Nistzschia } \\
\text { sp. }\end{array}$} & \multicolumn{2}{|c|}{$\begin{array}{c}\text { Navicula } \\
\text { sp. }\end{array}$} & \multicolumn{2}{|c|}{$\begin{array}{c}\text { Rhizosolenia } \\
\text { sp. }\end{array}$} \\
\hline & MR1 & MR2 & MR1 & MR2 & MR1 & MR2 & MR1 & MR2 & MR1 & MR2 & MR1 & MR2 & MR1 & MR2 \\
\hline Jan & 7.5 & 6.4 & - & - & 17 & 17.6 & 1.5 & 1.8 & 2 & 2.4 & 1.5 & 1.2 & - & - \\
\hline Feb & 11 & 13 & 0.44 & 0.29 & 34 & 37 & 2 & 1.8 & 2.3 & 2.1 & 2.2 & 2 & - & - \\
\hline March & 34 & 38 & - & - & 42 & 38 & 0.42 & 0.7 & - & - & - & - & - & - \\
\hline April & 56 & 58 & 0.62 & 0.5 & 35 & 32 & 1.2 & 1 & - & - & 0.5 & 0.36 & - & - \\
\hline May & 52 & 55 & 0.28 & 0.38 & - & - & - & - & - & - & - & - & - & - \\
\hline June & - & - & - & - & - & - & - & - & - & - & - & - & - & - \\
\hline July & - & - & - & - & - & - & - & - & - & - & - & - & - & - \\
\hline Aug & - & - & - & - & - & - & - & - & - & 0.4 & - & - & 0.72 & 0.6 \\
\hline Sept & - & - & 0.4 & - & - & - & - & - & 1.6 & 1.4 & 1.2 & 0.8 & 0.81 & 0.63 \\
\hline Oct & 6 & 7.5 & 10 & 11.2 & - & - & - & - & 14.4 & 16 & 4.2 & 4.5 & 1.2 & 1 \\
\hline Nov & 8.2 & 8 & 0.26 & 0.5 & 13 & 11 & 0.6 & 0.64 & 2.5 & 2.8 & 2.1 & 2.4 & - & - \\
\hline Dec & 11 & 9.7 & 1 & 0.8 & 16 & 14 & 1 & 0.82 & 2 & 2.2 & 0.56 & 0.42 & - & - \\
\hline
\end{tabular}

Table 2: Phytoplankton composition at different stations of Bhayandar saltpan (No./ml; values are $\times 10^{3}$ )

\begin{tabular}{|c|c|c|c|c|c|c|c|c|c|c|c|c|c|c|}
\hline \multirow[t]{2}{*}{ Month } & \multicolumn{2}{|c|}{$\begin{array}{c}\text { Dunaliella } \\
\text { sp. }\end{array}$} & \multicolumn{2}{|c|}{$\begin{array}{c}\text { Anabaena } \\
\text { sp. }\end{array}$} & \multicolumn{2}{|c|}{$\begin{array}{c}\text { Chlorella } \\
\text { sp. }\end{array}$} & \multicolumn{2}{|c|}{$\begin{array}{c}\text { Oscillatoria } \\
\text { sp. }\end{array}$} & \multicolumn{2}{|c|}{$\begin{array}{l}\text { Nistzschia } \\
\text { sp. }\end{array}$} & \multicolumn{2}{|c|}{$\begin{array}{c}\text { Navicula } \\
\text { sp. }\end{array}$} & \multicolumn{2}{|c|}{$\begin{array}{c}\text { Rhizosolenia } \\
\text { sp. }\end{array}$} \\
\hline & BH1 & BH2 & BH1 & $\mathrm{BH} 2$ & BH1 & BH2 & BH1 & BH2 & BH1 & BH2 & BH1 & BH2 & BH1 & BH2 \\
\hline Jan & 6 & 4.5 & - & - & 26 & 24 & 0.8 & 0.65 & 1.2 & 1 & 0.68 & 0.42 & - & - \\
\hline Feb & 8 & 7.5 & 0.5 & - & 28 & 32 & 0.52 & 0.6 & - & - & - & 0.24 & - & - \\
\hline
\end{tabular}




\begin{tabular}{|c|c|c|c|c|c|c|c|c|c|c|c|c|c|c|}
\hline March & 28 & 32 & 0.24 & 0.26 & 18 & 16.5 & 0.56 & 0.74 & - & - & - & - & - & - \\
\hline April & 54 & 49 & - & - & - & - & 0.8 & 1.2 & - & - & - & - & - & - \\
\hline May & 46 & 43 & - & - & - & - & - & - & - & - & - & - & - & - \\
\hline June & - & - & - & - & - & - & - & - & - & - & - & - & - & - \\
\hline July & - & - & - & - & - & - & - & - & - & - & - & - & - & - \\
\hline Aug. & - & - & - & - & - & - & - & - & - & - & - & - & - & - \\
\hline Sept & - & - & - & - & - & - & - & - & 1.2 & 1.4 & - & - & 1.6 & 2 \\
\hline Oct & - & - & 8 & 6.5 & - & - & - & - & 8.6 & 7.4 & 2.3 & 2 & 1.8 & 1.5 \\
\hline Nov & 4.6 & 3.8 & 0.22 & - & 16 & 20 & 0.5 & 0.74 & 1.5 & 1.7 & 0.5 & 0.62 & - & - \\
\hline Dec & 6 & 5.4 & - & - & 22 & 19 & 0.45 & 0.6 & 0.55 & 0.6 & - & - & - & - \\
\hline
\end{tabular}

Table 3: Zooplankton composition at Mira Road saltpan (No./l; values are $\times 10^{3}$ )

\begin{tabular}{|c|c|c|c|c|c|c|c|c|c|c|}
\hline \multirow{2}{*}{ Month } & \multicolumn{2}{|c|}{ Fabrea salina } & \multicolumn{2}{|c|}{ Brachionus } & \multicolumn{2}{|c|}{ Artemia nauplii } & \multicolumn{2}{|c|}{ Folliculina } & \multicolumn{2}{|c|}{ Euplotes } \\
\hline & $\mathrm{MR}_{1}$ & $\mathrm{MR}_{2}$ & $\mathrm{MR}_{1}$ & $\mathrm{MR}_{2}$ & $\mathrm{MR}_{1}$ & $\mathrm{MR}_{2}$ & $\mathrm{MR}_{1}$ & $\mathbf{M R}_{2}$ & $\mathrm{MR}_{1}$ & $\mathbf{M R}_{2}$ \\
\hline Jan & 12 & 15 & 8 & 10 & 1 & 3 & - & - & 2 & - \\
\hline Feb & 18 & 20 & 6 & 5 & 1 & - & - & - & 4 & 1 \\
\hline March & 44 & 38 & - & - & - & - & - & - & - & 2 \\
\hline April & 56 & 53 & - & - & 2 & - & - & - & - & - \\
\hline May & 58 & 52 & - & - & - & 2 & - & - & - & - \\
\hline June & 6 & 2 & 4 & - & - & - & - & - & - & - \\
\hline July & - & - & - & - & - & - & - & - & - & - \\
\hline Aug & - & - & - & - & - & - & - & - & - & - \\
\hline Sept & - & - & 2 & - & - & - & 4 & 2.6 & - & - \\
\hline Oct & 4 & 3 & - & 8 & - & - & 12 & 10 & - & - \\
\hline Nov & 8 & 11 & - & - & - & 1.5 & - & - & 4 & 2 \\
\hline Dec & 14 & 16 & - & 2 & - & - & - & - & 8 & 5 \\
\hline
\end{tabular}

Table 4: Zooplankton composition at Bhayandar saltpan (No./l; values are $\times 10^{3}$ )

\begin{tabular}{|c|c|c|c|c|c|c|c|c|c|c|}
\hline \multirow{2}{*}{ Month } & \multicolumn{2}{|c|}{ Fabrea salina } & \multicolumn{2}{|c|}{ Brachionus } & \multicolumn{2}{|c|}{ Artemia nauplii } & \multicolumn{2}{|c|}{ Folliculina } & \multicolumn{2}{|c|}{ Euplotes } \\
\hline & $\mathrm{BH}_{1}$ & $\mathrm{BH}_{2}$ & $\mathrm{BH}_{1}$ & $\mathrm{BH}_{2}$ & $\mathrm{BH}_{1}$ & $\mathrm{BH}_{2}$ & $\mathrm{BH}_{1}$ & $\mathrm{BH}_{2}$ & $\mathrm{BH}_{1}$ & $\mathrm{BH}_{2}$ \\
\hline Jan & 14 & 12 & 6 & 9 & 2 & - & - & - & - & - \\
\hline Feb & 24 & 27 & 8 & 4 & - & 4 & 4 & 3 & - & - \\
\hline March & 42 & 36 & - & - & 3 & 1 & 2 & - & - & - \\
\hline April & 52 & 47 & - & - & - & - & - & - & - & - \\
\hline May & 44 & 48 & - & - & 2 & - & - & - & - & - \\
\hline June & 8 & 5 & 11 & 8 & - & - & - & - & - & - \\
\hline July & - & - & - & - & - & - & - & - & - & - \\
\hline Aug & - & - & - & - & - & - & - & - & - & - \\
\hline Sept & - & - & - & 2 & - & - & - & - & - & 2 \\
\hline Oct & - & 3 & - & - & - & - & - & - & - & - \\
\hline Nov & 12 & 15 & 4 & 4 & - & - & 6 & 2 & 12 & 16 \\
\hline Dec & 16 & 12 & 1.6 & - & 1.6 & - & 12 & 9 & - & - \\
\hline
\end{tabular}

\section{Physical and chemical variables}

The highest water temperature $\left(39.0^{\circ} \mathrm{C}\right)$ was recorded at Bhayandar saltpan in May. The water $\mathrm{pH}$ was alkaline throughout the year, varying from 8.0 to 8.6. Salinity was very low during monsoon months, varying from nil to $16 \%$ contrary to its higher values (up to152\%) prevailing during late post- monsoon and pre- monsoon months. The levels of total alkalinity were generally low during monsoon months being $100 \mathrm{mg} \mathrm{L}^{-1}$ in July. The low 
DO levels (1.4- $3.4 \mathrm{mg} \mathrm{L}^{-1}$ ) were recorded during pre- and postmonsoon months. Generally, the dissolved free carbon dioxide was nil throughout the year. The values of $\mathrm{NH}_{4}{ }^{+}-\mathrm{N}, \mathrm{NO}_{2}-\mathrm{N}, \mathrm{NO}_{3}-\mathrm{N}$ and $\mathrm{PO}_{4}-\mathrm{P}$ were less during monsoon months and higher in postmonsoon periods. There was no wide variation in soil quality parameters at both the saltpans (Table 5,6). The ANOVA has revealed significant difference $(\mathrm{P}=0.05)$ in the values of all the
12 physical and chemical variables studied in various months. In addition, water temperature and $\mathrm{NO}_{2}-\mathrm{N}$ values showed significant difference at various stations too. There was strong positive correlation of Fabrea with water temperature, salinity, total alkalinity, and $\mathrm{PO}_{4}-\mathrm{P}$ while negative correlation with water depth and $\mathrm{pH}($ Table 7,8$)$.

Table 5: Soil-quality parameters of Mira Road saltpan.

\begin{tabular}{|c|c|c|c|c|c|c|}
\hline \multirow{2}{*}{ Parameter } & \multicolumn{2}{|c|}{ Pre monsoon } & \multicolumn{3}{|c|}{ Monsoon } & \multicolumn{2}{c|}{ Post monsoon } \\
\cline { 2 - 7 } & MR $_{\mathbf{1}}$ & $\mathbf{M R}_{\mathbf{2}}$ & MR $_{\mathbf{1}}$ & MR $_{\mathbf{2}}$ & MR $_{\mathbf{1}}$ & MR $_{\mathbf{2}}$ \\
\hline Sand (\%) & 35.0 & 35.4 & 37.2 & 37.3 & 36.0 & 36.5 \\
\hline Silt (\%) & 43.6 & 43.4 & 42.8 & 42.4 & 43.5 & 42.8 \\
\hline Clay (\%) & 21.4 & 21.2 & 20.0 & 20.3 & 20.5 & 20.7 \\
\hline Organic carbon (\%) & 0.75 & 0.72 & 0.50 & 0.55 & 0.61 & 0.64 \\
\hline Organic matter (\%) & 1.293 & 1.241 & 0.862 & 0.948 & 1.051 & 1.103 \\
\hline Total nitrogen (mg/100g of soil sample) & 75 & 73 & 50 & 55 & 60 & 63 \\
\hline Phosphorous (mg/100g of soil sample) & 4.3 & 4.2 & 4.0 & 4.0 & 4.1 & 4.4 \\
\hline
\end{tabular}

Table 6: Soil-quality parameters of Bhayandar saltpan.

\begin{tabular}{|c|c|c|c|c|c|c|}
\hline \multirow{2}{*}{ Parameter } & \multicolumn{2}{|c|}{ Pre monsoon } & \multicolumn{2}{|c|}{ Monsoon } & \multicolumn{2}{|c|}{ Post monsoon } \\
\hline & $\mathrm{BH}_{1}$ & $\mathrm{BH}_{2}$ & $\mathrm{BH}_{1}$ & $\mathrm{BH}_{2}$ & $\mathrm{BH}_{1}$ & $\mathrm{BH}_{2}$ \\
\hline Sand (\%) & 34.8 & 35.2 & 37.0 & 37.2 & 35.6 & 35.8 \\
\hline Silt (\%) & 42.6 & 43.0 & 42.0 & 42.6 & 43.0 & 43.5 \\
\hline Clay (\%) & 22.6 & 21.8 & 21.0 & 20.2 & 21.4 & 20.7 \\
\hline Organic carbon (\%) & 0.81 & 0.74 & 0.59 & 0.53 & 0.66 & 0.60 \\
\hline Organic matter (\%) & 1.396 & 1.276 & 1.017 & 0.914 & 1.138 & 1.034 \\
\hline Total nitrogen (mg/100g of soil sample) & 82 & 74 & 58 & 53 & 66 & 61 \\
\hline Phosphorous (mg/100g of soil sample) & 4.5 & 4.4 & 4.0 & 4.1 & 4.2 & 4.2 \\
\hline
\end{tabular}

Table 7: Statistical analysis of physical \& chemical variables and biological studies at Mira Road saltpan.

\begin{tabular}{|c|c|c|c|c|c|c|c|c|c|}
\hline \multicolumn{4}{|c|}{ Physico-chemical parameter } & \multicolumn{2}{|c|}{ F. salina } & \multicolumn{2}{|c|}{ Dunaliella } & \multicolumn{2}{|c|}{ Chlorella } \\
\hline & Min. & Max. & Mean \pm Std. dev. & $\mathrm{r}$ & $\mathrm{t}$ & r & $\mathrm{t}$ & $\mathrm{r}$ & $\mathrm{t}$ \\
\hline Temperature $\left({ }^{\circ} \mathrm{C}\right)$ & 25.8 & 38.4 & $29.679 \pm 4.259$ & 0.866 & 2.377 & 0.920 & 2.806 & 0.195 & 3.804 \\
\hline Depth $(\mathrm{cm})$ & 31.85 & 68.95 & $47.008 \pm 13.715$ & -0.767 & 3.107 & -0.740 & 3.332 & -0.602 & 4.510 \\
\hline $\mathrm{PH}$ & 8.0 & 8.6 & $8.417 \pm 0.180$ & -0.086 & -1.589 & 0.010 & -1.240 & -0.483 & -0.959 \\
\hline Salinity $(\% 0)$ & 1.0 & 121.0 & $50.083 \pm 44.544$ & 0.966 & 4.435 & 0.928 & 4.497 & 0.663 & 3.578 \\
\hline Alkalinity (mg/l) & 100.0 & 230.5 & $150.417 \pm 33.819$ & 0.717 & 19.259 & 0.689 & 18.921 & 0.137 & 13.519 \\
\hline DO (mg/l) & 2.5 & 8.0 & $4.775 \pm 1.953$ & -0.784 & -2.045 & -0.715 & -1.726 & -0.747 & -1.615 \\
\hline $\mathrm{DCO}_{2}(\mathrm{mg} / \mathrm{l})$ & 0.0 & 1.0 & $0.350 \pm 0.458$ & 0.292 & -2.959 & 0.242 & -2.593 & 0.170 & -2.764 \\
\hline $\mathrm{NH}_{4}^{+}-\mathrm{N}(\mathrm{mg} / \mathrm{l})$ & 0.145 & 1.315 & $0.549 \pm 0.425$ & 0.670 & -2.947 & 0.643 & -2.580 & 0.234 & -2.723 \\
\hline $\mathrm{NO}_{2}-\mathrm{N}(\mathrm{mg} / \mathrm{l})$ & 0.029 & 0.149 & $0.096 \pm 0.035$ & 0.846 & -2.987 & 0.810 & -2.625 & 0.644 & -2.811 \\
\hline $\mathrm{NO}_{3}-\mathrm{N}(\mathrm{mg} / \mathrm{l})$ & 1.170 & 2.900 & $1.783 \pm 0.541$ & 0.688 & -2.749 & 0.721 & -2.386 & 0.536 & -2.478 \\
\hline $\mathrm{PO}_{4}-\mathrm{P}(\mathrm{mg} / \mathrm{l})$ & 0.045 & 0.650 & $0.371 \pm 0.220$ & 0.750 & -2.960 & 0.682 & -2.594 & 0.492 & -2.606 \\
\hline
\end{tabular}




\section{Oceanography \& Fisheries Open access Journal}

Table 8: Statistical analysis of physical \& chemical variables and biological studies at Bhayandar saltpan.

\begin{tabular}{|c|c|c|c|c|c|c|c|c|c|}
\hline \multicolumn{4}{|c|}{ Physico-chemical parameter } & \multicolumn{2}{|c|}{ F. salina } & \multicolumn{2}{|c|}{ Dunaliella } & \multicolumn{2}{|c|}{ Chlorella } \\
\hline Tomnom & Min. & Max. & Mean \pm Std. dev. & $\mathrm{r}$ & $\mathrm{t}$ & $\mathrm{r}$ & $\mathrm{t}$ & $\mathrm{r}$ & $\mathrm{t}$ \\
\hline 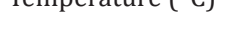 & 26.35 & 38.7 & $30.529 \pm 4.323$ & 0.801 & 3.014 & 0.906 & 4.231 & -0.357 & 5.275 \\
\hline Depth $(\mathrm{cm})$ & 28.55 & 66.4 & $44.963 \pm 11.313$ & -0.757 & 3.423 & -0.676 & 4.089 & -0.284 & 6.669 \\
\hline $\mathrm{PH}$ & 7.9 & 8.9 & $8.342 \pm 0.253$ & -0.411 & -1.603 & -0.359 & -0.752 & -0.222 & -0.258 \\
\hline Salinity $(\%)$ & 1 & 150 & $53.667 \pm 50.864$ & 0.957 & 3.729 & 0.889 & 4.043 & 0.263 & 3.135 \\
\hline Alkalinity (mg/l) & 104 & 264 & $147 \pm 42.780$ & 0.729 & 14.044 & 0.717 & 14.502 & -0.03 & 10.669 \\
\hline $\mathrm{DO}(\mathrm{mg} / \mathrm{l})$ & 1.4 & 8.1 & $4.850 \pm 2.330$ & -0.885 & -2.122 & -0.739 & -1.282 & -0.492 & -1.153 \\
\hline $\mathrm{DCO}_{2}(\mathrm{mg} / \mathrm{l})$ & 0 & 2.4 & $0.317 \pm 0.711$ & 0.581 & -3.291 & 0.596 & -2.298 & -0.068 & -2.59 \\
\hline $\mathrm{NH}_{4}-\mathrm{N}(\mathrm{mg} / \mathrm{l})$ & 0.08 & 1.26 & $0.531 \pm 0.361$ & 0.591 & -3.215 & 0.49 & -2.228 & 0.079 & -2.547 \\
\hline $\mathrm{NO}_{2}-\mathrm{N}(\mathrm{mg} / \mathrm{l})$ & 0.033 & 0.182 & $0.121 \pm 0.055$ & 0.821 & -3.264 & 0.697 & -2.288 & 0.531 & -2.669 \\
\hline $\mathrm{NO}_{3}-\mathrm{N}(\mathrm{mg} / \mathrm{l})$ & 1.195 & 2.64 & $1.758 \pm 0.443$ & 0.461 & -2.979 & 0.359 & -1.996 & 0.442 & -2.219 \\
\hline $\mathrm{PO}_{4}-\mathrm{P}(\mathrm{mg} / \mathrm{l})$ & 0.045 & 0.94 & $0.345 \pm 0.262$ & 0.897 & -3.255 & 0.821 & -2.267 & 0.171 & -2.606 \\
\hline
\end{tabular}

\section{Population of Fabrea salina}

F. salina was the most dominant species in microzooplankton community. Its density varied from zero in monsoon months to $55 \times 10^{3}$ cells $\mathrm{L}^{-1}$ in May. The population abundance was in strong correlation with salinity, temperature, alkalinity, water-depth, DO and $\mathrm{NO}_{2}-\mathrm{N}$. Fabrea flourishes well under the higher temperature (30-39º) and salinity (40-150\%) conditions. Dunaliella acts as natural food for Fabrea. The bloom of Dunaliella was noticed during March to May with the concurrent abundance of Fabrea.

\section{Cyst Hatching}

It is evident that 40 to $50 \%$ salinities are suitable for cyst hatching. No significant hatching occurred beyond $60 \%$ salinity.

\section{Discussion}

\section{Phyto and Zooplankton}

Dunaliella salina has best growth in $120 \%$ salinity with a tolerance limit of $350 \%$ [18]. Like Dunaliella, diatoms are also ubiquitous inhabitants of hypersaline environments, but they never appear to dominate. The present findings are in conformity with the occurrence of diatoms in solar salterns having salinity up to $129 \%$ in the Great Salt Lake [19]. Nitzschia sp. and Navicula sp. are represented in all these aquatic environments. The probable factors restricting the eukaryotic algae from many hypersaline environments include their inability to osmoregulation under prevailing conditions and to assimilate nutrients that may be scarce coupled with periodic habitat desiccation.

\section{Physical and Chemical Variables}

The saltpans are exposed typically to a wide range of environmental stress and perturbations. On solar heating of brines having halobacterial colouration, a maximum temperature of $46^{\circ} \mathrm{C}$ is attained by the densely colored brine, while the clear brines could reach up to $39^{\circ} \mathrm{C}$ [20]. Not only do gases diffuse more slowly as brine density increases, the capacity to hold them also becomes poor. Further the low DO levels in the present study were also probably due to bacterial consumption of oxygen that diffuses from the atmosphere or produced by microalga Dunaliella. The low $\mathrm{pH}$ levels indicate the high levels of $\mathrm{CO}_{2}$ and alkalinity in water bodies as observed in the present study. The noteworthy trend in salinity values were due to influx of freshwater during monsoon while prevailing higher temperature, excessive evaporation, and low water-depths in the summer months.

\section{Population of $F$ salina}

The present study reveals great ability of Fabrea to withstand wide ranges of environmental variables. Its better growth has been obtained at $6 \times 10^{6}$ and $8 \times 10^{6}$ Dunaliella cells $\mathrm{mL}^{-1}$ [9]. As observed, in solar salterns, it feeds voraciously upon Dunaliella cells (Figure 1). However, it appeared that Fabrea, in extremely saline conditions ( $>240 \%$ ) when Dunaliella is not available, survives on halobacterial and it subsists on bacteria during food scarcity [21]. In marine planktonic realm, nearly all phytoplankton produced are consumed, primarily by microzooplankton [22]. Protists are capable of sensing the biochemical properties of their prey cells $[23,24]$, and both ciliates and flagellates have been seen to feed preferentially on more nutritious phytoplankton species $[25,26]$ indicating why Dunaliella is preferred by Fabrea. Fabrea disappears from saltpans in monsoon months as it does not thrive well in brackish water. It forms cyst and resumes normal active form and life activities on the return of suitable conditions during mid of November [9]. 


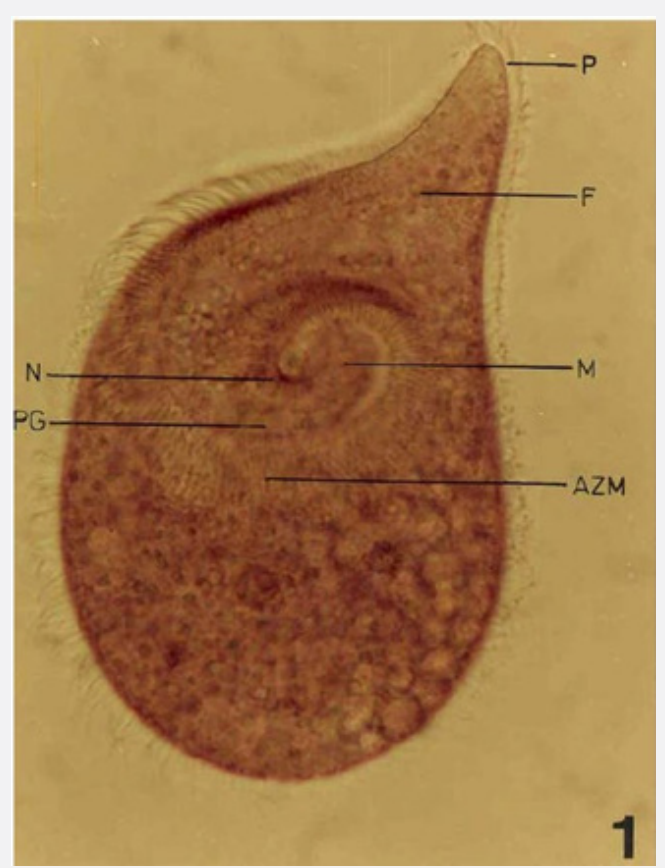

Figure 1: Fabrea salina (x40); adoral zone of membranelles (AZM), frontal field $(F)$, mouth area of buccal pouch (M), neuromotorium (N), peristomial groove (PG).

The positive correlation with nitrogen and phosphate is an indication of demand-supply of nutrients to sustain its higher densities in the month of April and May. The optimal production of solar salt requires a well-established balance between primary and secondary producers, with Artemia grazing on phytoplankton constitutes the major interaction [27]. Artemia also tolerates very high salinities [28]. It is surmised, therefore, that Fabrea too contributes to solar salt manufacture. Very sparse, heterogeneous distribution and above all almost vanished populations of Artemia from majority of saltpans along the Mumbai coastline make Fabrea as a predominant inhabitant of these solar saltworks [29]. The present knowledge of the ecology of Fabrea in its natural habitat and effective management practices can be applied for its controlled production on commercial scale in solar salt- beds [30]. The euryplasticity, easy acceptability of a variety of live and inert feeds, short generation period and biochemical composition make F. salina as an appropriate animal for studying microbiology of hypersaline environments.

\section{References}

1. Lee J J, Hutner S H and Bovee E C (1985) An illustrated guide to the protozoa. Society of Protozoologists, Allen Press, Kansas, US, Pp: 629.

2. Stoecker D K and Cappuzzo J M (1990) Predation on protozoa, its importance to zooplankton. Journal of Plankton Research 12: 891-908.

3. Sanders R W and Wickham S A (1993) Planktonic protozoa and metazoa:production, food quality and population control. Mar Microb Food Webs: 7:197-223.

4. Smetacek V (1991) Trophic behaviour-Session Summary. In: Philip C R, Carol M T and Peter H B (eds), Protozoa and their role in marine processes. Ecology Science 25: 195-203.
5. Post F J, Borowitzka L J, Borowitzka M A, Mackay B and Moulton T (1983) The protozoa of a Western Australian hypersaline lagoon. Hydrobiologia 105: 95-113.

6. Yufera M (1985) The population of Fabrea salina (Ciliata: Heterotrichida) in the Salterns of Cadiz bay. Invest Pesq Barc 49: 493-500.

7. Pandey B D and Yeragi S G (1998) Fabrea salina: Live food for use in aquaculture. Fish Chimes 18: 17-18.

8. Pandey B D and Yeragi S G (2000) The importance of live feeds in aquatic seed production. Infofish International 4: 31-36.

9. Pandey B D (2001) Ecology, biology, and culture aspects of Fabrea salina. University of Mumbai, India.

10. Pandey B D and Yeragi S G (2003) Preliminary and mass culture aspects on a heterotrichous ciliate, Fabrea salina. Aquaculture 232(1-4): 241-253.

11. Pandey B D, Yeragi S G and Pal A K (2004) Nutritional value of a heterotrichous ciliate, Fabrea salina with emphasis on its fatty acid profile. Asian-australasian Journal of Animal Sciences 17(7): 995-999.

12. Marangoni R, Puntoni S, Favati L and Colombetti G (1994) Phototaxis in Fabrea salina. I. Action spectrum determination. Journal of Photochemistry and Photobiology B: Biology 23: 149-154.

13. Marangoni R, Batistini A, Puntoni S and Colombetti G (1995) Temperature effects on motion parameters and phototactic reaction of the marine ciliate Fabrea salina. Journal of Photochemistry and Photobiology B: Biology 30: 123-127.

14. Marangoni R, Gobbi L, Verni F, Albertini G and Colombetti G (1996) Pigment granules and hypericin- like fluorescence in the marine ciliate Fabrea salina. Acta Protozoologica 35: 177-182.

15. Marangoni R, Preosti G and Colombetti G (2000) Phototactic orientation mechanism in the ciliate Fabrea salina, as inferred from numerical simulations. Journal of Photochemistry and Photobiology B: Biology 54: 185-193. 
16. Puntoni S, Maramgoni R, Gioffre and Colombetti G (1998) Effects of $\mathrm{Ca}^{2+}$ and $\mathrm{K}^{+}$on motility and photomotility of the marine ciliate $\mathrm{Fab}$ rea salina. Journal of Photochemistry and Photobiology B: Biology 43: 204-208.

17. Ghosh A B, Bajaj J C, Hasan R and Singh D (1983) Soil and water testing methods A laboratory manual. Indian Agricultural Research Institute, New Delhi, India

18. Leoblich L A (1972) Studies on the brine flagellate Dunaliella salina. University of California. San Diego, US, P. 142.

19. Felix E A and Rushforth S R (1979) The algal flora of the Great Salt Lake, Utah, USA. Nova Hedwigia 31: 163-194.

20. Javor B J (1983) Planktonic standing crop and nutrients in a saltern ecosystem. Limnology and Oceanography 28(1): 153-159.

21. Repak A J (1983) Suitability of selected marine algae for growing the marine heterotrich ciliate Fabrea salina. The Journal of Protozoology 30: 52-54.

22. Strom S (2002) Novel interactions between phytoplankton and microzooplankton: their influence on the coupling between growth and grazing rates in the sea. Hydrobiologia 480: 41-54.

23. Monger B C, Landry M R and Brown L S (1999) Feeding selection of heterotrophic marine nanoflagellates based on the surface hydrophobicity of their picoplankton prey. Limnology and Oceanography 44 : 1917-1927.
24. Strom S L, Wolfe G V and Slajer A (2001) Phytoplankton DMSP release: a possible chemical defense against protist grazers?, Amer Soc Limnol Oceanogr.

25. Stoecker D K, Cucci T L, Hulburt E M and Yentsch C M (1986) Selective feeding by Balanion sp. (Ciliata: Balanionidae) on phytoplankton that best support its growth. Journal of Experimental Marine Biology and Ecology 95: 113-130.

26. Buskey E J (1997) Behavioural components of feeding selectivity of the heterotrophic dianoflagellate Protoperidinium pellucidum. Marine Ecology Progress Series 153: 77-89.

27. Tackaert W and Sorgeloos P (1993) The use of brine shrimp Artemia in biological management of solar saltworks. In: Seventh Symposium on Salt. Elsevier Science Publishers B V, Amsterdam, Netherlands Pp: 617-622.

28. Ludwig C Naegel and Sonia AR (2002) Ecological observations and biomass proximate composition of the brine shrimp Artemia (Crustacea: Anostraca) from Pichilingue, Baja California Sur, México. Hydrobiologia, 486: 185-190.

29. APHA (1992) Standard Methods for The Examination of Water and Wastewater. Washington, DC.

30. Demar-Gervais C, Genermont J (1971) Donnees expeimentales sur le mecanisme de l'eclosion des kystes de Fabrea salina. Protistologica 7: 421-433.

Your next submission with Juniper Publishers will reach you the below assets

- Quality Editorial service

- Swift Peer Review

- Reprints availability

- E-prints Service

- Manuscript Podcast for convenient understanding

- Global attainment for your research

- Manuscript accessibility in different formats ( Pdf, E-pub, Full Text, Audio)

- Unceasing customer service

Track the below URL for one-step submission https://juniperpublishers.com/online-submission.php 